\title{
Kinship Care: A Cross-Case Analysis of Grandparents Raising Grandchildren in the Filipinos' Cultural Context
}

\author{
Huemer O. Uy ${ }^{1 *}$ and Jonaid M. Sadang ${ }^{2}$ \\ ${ }^{1}$ College of Nursing, Cebu Normal University, 6000, Cebu City, Philippines \\ ${ }^{2}$ College of Health Sciences, Mindanao State University, 9700, Marawi City, Philippines \\ *Correspondence: huemer.uy@gmail.com \\ Type of the Paper (Article) \\ Received: November 7, 2020; Accepted: February 12, 2021; Published: March 14, 2021 \\ https://doi.org/10.29253/achnr.2020.24459
}

\begin{abstract}
Filipino families commonly have members beyond the nuclear family structure who are usual sources of mutual support, protection and interdependence for the family. Among these are grandparents who are valuable sources of support including childcare. Using multiple case study approach with cross-case analysis, the circumstances of seven Filipino grandparents raising grandchildren were examined. Their extrinsic reasons for taking custody over their grandchildren include parental employment, parents having new families, lack of basic parenting skills, substance abuse, teenage pregnancy, unstable home environment and domestic violence, child abuse and negligence, parental imprisonment, and financial incapability of the parents to raise the child; while the intrinsic reason being the grandparent's need for home companionship. Filipino grandparents' reasons for taking grandchild custody were found to be consistent with other grandparents around the world who also took custody of their grandchildren.
\end{abstract}

Keywords: gerontology; kinship care; Filipino; multiple case study; cross-case analysis

\section{Introduction}

Filipino families commonly have members beyond the nuclear family structure who are usual sources of mutual support, protection and interdependence of the whole family (Jimenez, 2015). Among these are grandparents who are valuable sources of financial, emotional and spiritual support, and may usually get involved in childcare. In households where both husband and wife assumes full-time careers, Filipino grandparents normally assume caring responsibilities over their grandchildren especially when nannies become less available because of the increasing workforce demand in various industries (Villegas, 2017).

The Filipino cultural norms such as "utang na loob" or mutual reciprocity, 'pakikisama' which means family unity and closeness, and serving as responsible role models to the younger generation made Filipino grandparents view their caregiving roles as a normative process rather than a burden (Kataoka-Yahiro et al, 2004). For some grandparents, the youthful presence of their grandchildren keep them alive and healthy (Sampson et al, 2015), and assuming the childcare functions has even afforded them with an increased sense of life purpose, more opportunities to strengthen family relationships and pass on family traditions, and experience love and companionship from family members (Hsieh et al, 2017; Silverstein, 2007). 
Despite that, the additional responsibility of proxy parenting has brought negative effects to these population group such as giving up leisure opportunities to prioritize childcare, abandonment of their plans for retirement because of their assumed role (O'Dell, 2011), developing financial strains from additional expenses for the grandchild under custody (Lent et al, 2018; Marriner, 2015; Waldrop et al, 2001), experiencing depression (Blustein et al, 2004; Minkler, et al., 2000) and other mental health issues caused by feelings of shame and guilt about their adult child's inability to raise the children (Lent et al, 2018). Becoming a custodial grandparent could have various consequences and this includes personal, interpersonal, and economic effects (Fauziningtyas et al, 2019; Hayslip et al, 2005). Some grandparents may even experience social isolation to prevent peers from knowing their situation, as some of their peers from the same age group are no longer parenting (Lent et al, 2018). Within the family, a grandparents' relationship with other family members may also suffer as grandparents tend to spend too much time on the child under their custody, while not spending enough time with other family members and relationships outside the family (Lent et al, 2018; O'Dell, 2011).

Moreover, because of the child's negative behavior, a grandparent's negative role adjustment, marital status, socioeconomic status, race/ethnicity, lack of support, family conflict, and poor physical health (Martin, 2015), the additional responsibility of childcare among grandparents negatively impacts self-care habits, which leads some health problems including obesity and worsening of the existing chronic health conditions (Hadfield, 2014). Thus, despite being manageable, parenting their own grandchildren is not a self-rewarding experience for some grandparents (Woodson-Robinson, 2010). By prioritizing the needs of children and viewing childcare as an important role that highly influences a child's character and success as a grownup, the society tends to neglect that grandparents, too, have special needs that must be met in order to maintain their health and quality of life. This study explored the situation of the Filipino grandparents and their reasons for assuming custodial roles and responsibilities over their grandchildren. It also examined the profile of Filipino grandparents who are acting as parents to their grandchildren.

\section{Methods}

Multiple case study using cross-case analysis approach was used to investigate the various situations of grandparents who are raising their respective grandchildren in the Philippines. It was adopted as it allows the researchers to investigate the phenomenon using a replication strategy, which is comparable to conducting several separate experiments on related topics (Zach, 2006). Such approach facilitates an in-depth comparison of individual cases and supports a comprehensive exploration of research questions and theory development (Straubert et al, 2011). This design asserts the importance of multiple case study approach to augment the study's external validity or generalizability by examining the variations across cases (Hardiman, 2005). Data triangulation was also adopted where researchers have collected the data from the participants at different points in time considering the availability of the target samples of this study. This application improves the reliability and validity of data as the strength of one method may help compensate the weakness of another (Straubert et al, 2011).

Participants were selected using purposive sampling based on the set criteria such as: (a) must be a Filipino grandparent with the responsibility of caring for at least one grandchild, either temporarily or permanently, and (b) willing to participate without any expected compensation. Seven (7) grandparents from Cebu City, five of whom are senior citizens volunteered and gave consent to be part of this study. Participants were interviewed using a semi-structured guide questionnaire that aimed at solving the main question; "What situations prompted the Filipino grandparents to assume the caring role for their grandchildren?". Their family circumstances were examined, and similarities were compared until a pattern was established. The findings were then compared to studies done in other countries. Such process of data triangulation improves the internal validity by ensuring the reliability or "dependability" of the findings (Merriam \& Tisdell, 2009).

Panel of ethics and qualitative experts from Mindanao State University and Cebu Normal University were consulted prior to the initiation of this study to assure that research protocols in conducting multiple case study were carefully observed. Written consent was also adopted to ensure that participation is voluntary and that they can refuse anytime during the data gathering process. Purpose, procedures, benefits, and risk of participation were carefully discussed for each participant. Coding (e.g., Case 1) was also used for confidentiality and privacy of any information coming from the participants. Audio-recording and transcripts of verbatim conversation were secured in a password-protected computer. 


\section{Results \& Discussion}

There were seven (7) participants who are involved in this study ages between 47 - 67 years. Crosscase analysis was performed by examining the data which were then organized into tables. Table 1 shows the profile of the grandparents and some details of their custodial roles. Majority of the participants are female, and represent varying marital status, social class and all of whom are functional and are able to perform childcare. The participants' family situations compelled them to take the childcare role once again, in order to ensure that a responsible adult will be raising their grandchildren.

\section{Case 1}

A 62 years old with three children and two grandchildren and separated from her husband. Both of her grandchildren are placed under her care for the past three years, while the children's mother is working in the Middle East as a Nurse for the past three years and regularly provides financial support. The children's father already has a new family, does not provide financial support and barely contacts his daughters.

\section{Case 2}

A 67-year-old retired public school teacher, widowed with five children with thirteen grandchildren. One grandchild (female, 15 years old) is placed under her care for the past seven years, while the child's parents already have their own separate families. Both are not providing financial support for their children. As such, their grandparent who is previously living alone after her husband died took care of the grandchild so she can have a companion at home.

\section{Case 3}

A 64-year-old widower with two daughters and four grandchildren. One grandchild (male, 9 years old) is under his care for the past two years. The boy's 34-year-old single mother is working in the United States and sends financial support on a monthly basis. They have no contact with the boy's alcoholic father and are unaware of his whereabouts.

\section{Case 4}

A 58-year-old market vendor, separated with four children and six grandchildren. Two of her grandchildren (both male at 8 and 10 years old) are left under her care for the past five years. Her son, the children's father, who physically abuses the children, was alcoholic and jobless for a long time, and is currently in jail for robbery. The children's battered mother left their father six years ago, and already with her new family in the province.

\section{Case 5}

A 47-year-old street food vendor, a single parent with two children and two grandchildren. One grandchild (female, 6 years old) was placed under her care since birth. Her daughter, the child's mother, got pregnant at the age of 16 , while child's father was also a minor at that time. Currently, the child's father did not finish his studies, has no stable job and does not provide child support. The child's mother who is currently 22 years of age is working as stay-in housemaid and visits her daughter only during weekends.

\section{Case 6}

A 66-year-old fruit vendor, married with two daughters and one grandchild (female, 12 years old) who are placed under her care for the past 2 years. Susan's younger daughter (the child's mother), who did not enter college, currently has an unstable income as a laundry woman and refuses to leave her abusive husband, despite being advised multiple times. The child's alcoholic father, who works as an electrician, has temper issues with a history of hitting his wife. Susan insisted to take her grandchild under her care for the fear of being abused or molested by the father. Lastly,

\section{Case 7}

A 64-year-old fast food vendor, married with four children and five grandchildren. Since last year, one grandchild (female, 5 years old) has been placed under her care. Both child's parents are call center representatives and had just recently got separated when the child's father was caught seeing another 
woman. The child's mother, participant daughter, is unable to watch after the child, as she works fulltime in order to financially support her daughter.

Participants' reasons for assuming the kinship care are mostly driven by circumstances where their grandchildren's biological parents are unable to perform proper childcare as seen in Table 2. Most of these contributed to extrinsic reasons, which pertain to the situation of the parents and their children that prompted them to take the child custody. Among the reasons extracted, only one was considered intrinsic, which refers to the personal reason of the grandparent in assuming child custody. Grandparents who are taking care of their grandchildren are a mixture of fun and hard work (Fauziningtyas et al, 2019). They feel self-fulfilled and less depressed when grandparental caregiving enhances their familial relationships (Tang et al, 2016). The happiness and companionship they get while taking care of their grandchildren are factors why most grandparents chose to share the responsibility of parenting (Fauziningtyas et al, 2019; Hayslip et al, 2005). Grandparents usually experience the sense of purpose in life at their age, which includes the opportunity to ensure and nurture their family relationships as well as receive love and companionship while enjoying their retirement years (Sampson et al, 2015). Grandparents consider this role as part of parenthood and their family obligation (Tang et al, 2016).

Extrinsic reasons include parental career overseas or a fulltime local job, parents having another family, lacking basic parenting skills, alcohol abuse, teenage pregnancy, unstable home environment and domestic violence, physical abuse to the child and parental neglect, imprisonment of a parent, and financial incapability of the parents to raise the child. Family crises are known factors why kinship care among grandparents is a common scenario most especially among developing countries including The Philippines (Fauziningtyas et al, 2019). Saxena et al (2013) and The American Academy of Child and Adolescent Psychiatry (2016) upholds the same reasons why the role of grandparents in childcare remains high in the United States, along with other reasons such as parental death and disability and increased parental deportation rates caused by immigration issues. Such reasons are also supported by Gaille (2017) where $40 \%$ of children under their grandparent's custody have at least one parent with substance abuse, and $28 \%$ were victims of abuse, abandonment, and parental neglect.

These factors are also consistent with the study of Sampson et al (2015) where most of the grandchildren who are living with the custody of their grandparents are victims of trauma or abuse from their respective parents. Some were neglected without food or clothing when they were taken by their grandparents and others were physically and or sexually abused (Fauziningtyas et al, 2019; Sampson et al, 2015). In western countries including United States of America, most grandparents assume the role of kinship care when their children have problems (e.g. substance abuse, early pregnancy) prohibiting them from taking care of their expected responsibilities as parents (Fauziningtyas et al, 2019). Most grandparents fulfill this function as results of marital instability of their children (Tang et al, 2016). The guilt of disappointment with their children usually left most grandparents' feeling that they have failed raising them, thus influencing their decision to assume the role of parenting in behalf of their children (Sampson et al, 2015). 
Table 1. Cross-case analysis of the grandparents' profiles and situations.

\begin{tabular}{|c|c|c|c|c|c|c|c|c|c|c|}
\hline $\begin{array}{l}\text { Case } \\
\text { No. }\end{array}$ & $\begin{array}{l}\text { Gender of } \\
\text { grandparent }\end{array}$ & $\begin{array}{l}\text { Age of } \\
\text { grand } \\
\text { parent }\end{array}$ & $\begin{array}{l}\text { Current Income } \\
\text { Source of the } \\
\text { Grandparent }\end{array}$ & $\begin{array}{l}\text { Marital } \\
\text { Status }\end{array}$ & $\begin{array}{l}\text { Total } \\
\text { Number } \\
\text { of } \\
\text { children }\end{array}$ & $\begin{array}{l}\text { Total } \\
\text { Number } \\
\text { of grand } \\
\text { children }\end{array}$ & $\begin{array}{l}\text { Number } \\
\text { of grand } \\
\text { children } \\
\text { under } \\
\text { custody } \\
\end{array}$ & $\begin{array}{l}\text { Age of } \\
\text { grand } \\
\text { children } \\
\text { under } \\
\text { custody } \\
\end{array}$ & $\begin{array}{l}\text { Gender of } \\
\text { grand } \\
\text { children } \\
\text { under } \\
\text { Custody } \\
\end{array}$ & $\begin{array}{l}\text { Length of time } \\
\text { grand child is } \\
\text { under custody }\end{array}$ \\
\hline 1 & Female & 64 & $\begin{array}{l}\text { Financial support } \\
\text { from her daughter } \\
\text { abroad }\end{array}$ & Separated & 3 & 2 & 2 & $9 \& 14$ & $\begin{array}{l}\text { Both } \\
\text { Female }\end{array}$ & 3 years \\
\hline 2 & Female & 67 & Retirement pension & Widow & 5 & 13 & 1 & 15 & Female & 7 years \\
\hline 3 & Male & 64 & $\begin{array}{l}\text { Financial support } \\
\text { from her daughter } \\
\text { abroad }\end{array}$ & Widower & 2 & 4 & 1 & 9 & Male & 2 years \\
\hline 4 & Female & 58 & $\begin{array}{l}\text { Income as a market } \\
\text { vendor }\end{array}$ & Separated & 4 & 6 & 2 & $8 \& 10$ & Both Male & 5 years \\
\hline 5 & Female & 47 & $\begin{array}{l}\text { Income as a street } \\
\text { food vendor }\end{array}$ & Unmarried & 2 & 2 & 1 & 6 & Female & 6 years \\
\hline 6 & Female & 66 & $\begin{array}{l}\text { Income as a fruit } \\
\text { vendor }\end{array}$ & Married & 2 & 1 & 1 & 12 & Female & 2 years \\
\hline 7 & Female & 64 & $\begin{array}{l}\text { Income as a fast } \\
\text { food vendor }\end{array}$ & Married & 4 & 5 & 1 & 5 & Female & 1 year \\
\hline
\end{tabular}


Table 2. Cross-case analysis of the grandchildren profiles and their parents.

\begin{tabular}{|c|c|c|c|c|}
\hline $\begin{array}{l}\text { Case } \\
\text { No. }\end{array}$ & $\begin{array}{l}\text { Situation of the } \\
\text { grandchild under } \\
\text { custody }\end{array}$ & Parents' situation & $\begin{array}{l}\text { Extrinsic Reasons for taking child } \\
\text { custody }\end{array}$ & $\begin{array}{l}\text { Intrinsic Reasons for } \\
\text { taking child custody }\end{array}$ \\
\hline 1 & $\mathrm{~N} / \mathrm{A}$ & $\begin{array}{l}\text { Father has a new family and barely contacts his } \\
\text { daughters and her mother is working in the } \\
\text { Middle East for the past } 3 \text { years. }\end{array}$ & $\begin{array}{l}\text { Parent has a new family and working } \\
\text { overseas. }\end{array}$ & $\mathrm{N} / \mathrm{A}$ \\
\hline 2 & $\begin{array}{l}\text { Torn in the middle of } \\
\text { her parents' new } \\
\text { families. }\end{array}$ & Both parents have a new family. & Both parents have separate families. & $\begin{array}{l}\text { Took custody of the } \\
\text { grandchild, so she can } \\
\text { have a companion at } \\
\text { home. }\end{array}$ \\
\hline 3 & $\mathrm{~N} / \mathrm{A}$ & $\begin{array}{l}\text { Father is alcoholic, have lost contact with his son, } \\
\text { and the whereabouts are unknown. Mother is } \\
\text { working in the United States for the past } 2 \text { years. }\end{array}$ & $\begin{array}{l}\text { Parent has an overseas career and substance } \\
\text { abuse of a parent. }\end{array}$ & $\mathrm{N} / \mathrm{A}$ \\
\hline 4 & $\begin{array}{l}\text { Both were physically } \\
\text { abused by the father } \\
\text { and have been left to } \\
\text { starve. }\end{array}$ & $\begin{array}{l}\text { Father is alcoholic and jobless for a longtime and } \\
\text { was imprisoned for robbery. Mother was a } \\
\text { battered wife; left her sons six years ago, eloped } \\
\text { with another man, and now have a new family in } \\
\text { the province. }\end{array}$ & $\begin{array}{l}\text { Parent has a new family, lacks basic } \\
\text { parenting skills, substance abuse of a parent, } \\
\text { unstable home environment and domestic } \\
\text { violence, child abuse, parental neglect and } \\
\text { imprisonment, and financial incapability of } \\
\text { the parents. }\end{array}$ & $\mathrm{N} / \mathrm{A}$ \\
\hline 5 & $\mathrm{~N} / \mathrm{A}$ & $\begin{array}{l}\text { Early age parental role (mother was } 16 \text { when she } \\
\text { got pregnant whereas their father was only } 15 \\
\text { years of age). Both did not finish their studies, } \\
\text { with no stable job and income. }\end{array}$ & $\begin{array}{l}\text { Parent has fulltime job locally, lacks basic } \\
\text { parenting skills, teenage pregnancy, and } \\
\text { financial incapability of the parents. }\end{array}$ & $\mathrm{N} / \mathrm{A}$ \\
\hline 6 & $\mathrm{~N} / \mathrm{A}$ & $\begin{array}{l}\text { Father was alcoholic, has temper issues with a } \\
\text { history of hitting his wife. Mother has no stable } \\
\text { job and refuses to leave her abusive husband. }\end{array}$ & $\begin{array}{l}\text { Substance abuse of a parent and unstable } \\
\text { home environment and domestic violence. }\end{array}$ & $\mathrm{N} / \mathrm{A}$ \\
\hline 7 & $\mathrm{~N} / \mathrm{A}$ & $\begin{array}{l}\text { Both parents are call-center agents. Their father } \\
\text { was caught seeing another woman and was left by } \\
\text { his wife because of it. }\end{array}$ & $\begin{array}{l}\text { Parents have fulltime job locally and unstable } \\
\text { home environment and domestic violence. }\end{array}$ & $\mathrm{N} / \mathrm{A}$ \\
\hline
\end{tabular}




\section{Conclusion and Implications}

Filipino grandparents raising their grandchildren have a lot in common with other grandparents raising children worldwide. Their family situations prompted them to assume the parenting role once again to ensure that their grandchildren are provided for, guided and well-protected. However, aside from dealing with their family's predicament, the grandparents end up sacrificing their energy and finances for childcare and may end up not having enough for their self-care needs. Overall, minimizing the family situation's emotional and psychological impact on the children is attained at the expense of their grandparents, rendering the older population real victims of their family's quandary.

Filipino grandparents' assumption of the childcare role does not come with social benefits or assistance to provide cushion against financial, emotional, psychological and physical burden to the grandparents involved. The lack of social recognition and support toward Filipino grandparents raising their grandchildren has placed an unsupported burden to the older persons. In addition of having confronted with their family's ordeal, being the usual provider of wisdom and support, these grandparents end up making most of the sacrifices for their family members without receiving any support from the society. As such, the Philippine government, being responsible for acting in the best interests of its citizens, should recognize the situations of these grandparents and be able to draft policies that will provide them leverage, despite their current situation. Laws and social programs should be developed to support the needs of these grandparents carrying additional burden on behalf of their family members.

\section{References}

American Academy of Child and Adolescent Psychiatry (2016). Grandparents Raising Grandchildren.https://www.aacap.org/AACAP/Families_and_youth/Facts_for_Families/FFFGuide/ Grandparents-Raising-Grandchildren-077.aspx

Blustein, J., Chan, S., Guanais, F. C. (2004). Elevated depressive symptoms among caregiving grandparents. Health Services Research, 39(6); 1671-1690.

Fauziningtyas, R., Indarwati, R., Alfriani, D., Haryanto, J., Ulfiana, E., Efendi, F., Nursalam, N., Abdullah, K. L. (2019). The experiences of grandparents raising grandchildren in Indonesia. 23(1); 17-26. http://dx.doi.org/10.1108/WWOP-10-2018-0019

Gaille, B. (2017). 23 Statistics on Grandparents Raising Grandchildren. https://brandongaille.com/21-statisticson-grandparents-raising-grandchildren/

Hadfield, J. C. (2014). The health of grandparents raising grandchildren: A literature review. Journal of Gerontological Nursing, 40(4), 32-42; quiz 44-5. http://dx.doi.org/10.3928/00989134-20140219-01

Hardiman, E. P. (2005). Factors contributing to new teacher understanding of the xaverian educational charism: A case study with cross case analysis (Order No. 3173667). https://search.proquest.com/docview/305028249?accountid=173015

Hayslip, B. Jr., Kaminski, P. L. (2005). Grandparents Raising Their Grandchildren: A Review of the Literature and Suggestions for Practice. The Gerontologist. 45(2); 262-269.

Hsieh, J. Y., Mercer, K. J., Costa, S. A. (2017). Parenting a second time around: The strengths and challenges of Indigenous grandparent caregivers. Grand Families: The Contemporary Journal of Research, Practice and Policy, 4(1); 8.

Jimenez, J. O. (2015). Transnational parenting: The experience of Filipino immigrant mothers who have left their children in the Philippines. Alliant International University.

Kataoka-Yahiro, M. R., Ceria, C., Yoder, M. (2004). Grandparent caregiving role in Filipino American families. Journal of cultural diversity, 11(3).

Lent, J. P., \& Otto, A. (2018). Grandparents, Grandchildren, and Caregiving: The Impacts of America's Substance Use Crisis. Generations, 42(3), 15-22.

Martin, D. E. (2015). The psychological effects of caregiving for grandchildren.

Merriam, S. B. \& Tisdell, E. J. (2009). Qualitative Research: A Guide to Design and Implementation, 4th Edition. John Wiley \& Sons.

Minkler, M., Fuller-Thomson, E., Miller, D., Driver, D. (2000). Grandparent caregiving and depression. In B. Hayslip, Jr. \& R. Goldberg-Glen (Eds.), Grandparents raising grandchildren: Theoretical, empirical, and clinical perspectives (pp. 207-219). New York, NY, United States.

O'Dell, H. (2011). To examine how the role has changed from grandparents to parenting grandparents (Order No. 1519607). 
Sampson, D., \& Hertlein Ph D, K. (2015). The experience of grandparents raising grandchildren. Grandfamilies: The contemporary journal of research, practice and policy. 2(1); 4.

Saxena, D., \& Brotherson, S. (2013, April). When Grandparents Become Parents to Their Grandchildren. North Dakota State University Publications Retrieved from https://www.ag.ndsu.edu/publications/homefarm/when-grandparents-become-parents-to their-grandchildren

Silverstein, M. (2007). Benefits of grandparents raising grandchildren. Journal of Intergenerational Relationships, 5(3), 131-134.

Straubert, H., Carpenter, D. (2011). Qualitative Research in Nursing Advancing the Humanistic Imperative (5 ${ }^{\text {th }}$ Edition). Lippincott Williams \& Wilkins.

Tang, F., Xu, L., Chi, I., Dong, X. Q. (2016). Psychological Well-Being of Older Chinese-American Grandparents Caring for Grandchildren. American Geriatrics Society. 64; 2356-2361. http://dx.doi.org/10.1111/jgs.14455

Villegas, B. M. (2017, October 26). The joys of Filipino grandparents. Manila Bulletin. Retrieved from https://news.mb.com.ph/2017/10/26/the-joys-of-filipino-grandparents/

Waldrop, D. P., \& Weber, J. A. (2001). From grandparent to caregiver: The stress and satisfaction of raising grandchildren. Families in Society, 82(5), 461-472. http://dx.doi.org/10.1606/1044-3894.177

Woodson-Robinson, A. (2010). An investigation of parental stress among urban grandparents in raising their grandchildren (Order No. 3389887).

Zach, L. (2006). Using a multiple-case studies design to investigate the information-seeking behavior of arts administrators. Library trends, 55(1), 4-21. 